\title{
Knowledge, and Screening Behaviours of Saudi Female Teachers Towards Breast Cancer in Description Buraydah, Saudi Arabia
}

sharifa khalid alduraibi ( $\nabla$ dr.s.alduraibi@gmail.com )

Research article

Keywords: knowledge, breast cancer, diabetes, breast self-examination, female teacher, Saudi Arabia

Posted Date: April 24th, 2020

DOI: https://doi.org/10.21203/rs.3.rs-20202/v1

License: (-) (1) This work is licensed under a Creative Commons Attribution 4.0 International License. Read Full License 


\section{Abstract}

Backgroun Breast cancer is the second commonest cause of cancer-related deaths in Saudi Arabia and the commonest type of female cancer. However, unfortunately several women bypass early discovery and management possibilities related to the shortage of data, knowledge, and recognition of breast cancer, as well as cancer screening manners in general. This study aims to assess the knowledge, and screening behaviour of female teacher regarding breast cancer.

Methods This cross-sectional study was conducted in the governmental secondary girls' schools in Buraydah city, Saudi Arabia, during the period 2018-2019. A cluster multistage random sampling technique was used to recruit female teacher. The data were collected through a self-administered questionnaire.

Results The study included 316 female teachers. The age of $55.4 \%$ of them was below 40 years. The total breast cancer knowledge score was abnormally distributed, as evidenced by significant Shapiro-Wilk test, $\mathrm{p}<$ 0.001 . The mean \pm SD score was $10.66 \pm 3.73$ (maximum possible score was 15 ) and the median (IQR) was 11 (8-13). Less than half (42.7\%) of the teachers reported performing BSE while only $9.5 \%$ went to a clinic for clinical breast examination. BSE was performed on monthly basis by only $14.8 \%$ of those practiced it. Ignorance of the examination and fear to discover a tumour were mentioned by $24.9 \%$ for each as a reason for not performing BSE whereas $42.5 \%$ of those who did not practice it had no reason for that. Mammogram was ever practiced by $22.5 \%$ of the female teachers. About one-third of the participants $(33.5 \%)$ claimed that they will perform mammogram in the coming year. Older teachers $(40-50)$ reported higher rates of performing mammogram compared to those aged $<40, p=0.012$. Also, teachers who had friends with breast cancer were practiced mammogram at higher rated than their counterparts, $p=0.025$.

Conclusions The study indicates that breast cancer knowledge among governmental female secondary school teachers in Buraydah city, Saudi Arabia is overall insufficient, regarding risk factors and clinical presentation. Performance of breast cancer screening techniques is not enough. Improving knowledge regarding breast cancer risk factors, presentation and screening tools as BSE and mammogram through educational programs is highly recommended for prevention and early detection.

\section{Background}

Breast cancer (BC) is the commonest cancer of women worldwide with nearly1.7 million new cases of BC were diagnosed in 2012 which represents $25 \%$ of all women cancers and fifth most common cause of death in women ${ }^{1}$. The worldwide rate for mortality from BC ranged between 6 per 100,000 in Eastern Asia to 20 per 100,000 in Western Africa².

Breast cancer is the second commonest cause of cancer-related deaths in Saudi Arabia and the commonest type of female cancer ${ }^{3-5}$. In Saudi Arabia, the incidence rate of breast cancer was $1 \%$ according to the Saudi Cancer Registry (2001-2008) ${ }^{6}$, and the overall survival rate was lower than those reported in United Kingdom and United States of America ${ }^{7}$; mostly this attributed to due to the non-existence of a standard nationwide breast screening program in the kingdom and low uptake of screening ${ }^{8}$. 
According to the recommendations from the Society of Breast Imaging and the $\mathrm{ACR},{ }^{9}$ women have a sense to recognize and describe any breast abnormalities immediately to their healthcare providers through breast selfexamination (BSE). In order to slow down the rising incidence of breast cancer, hindering of the increasing prevalence of its risk factors accompany improving economic conditions is recommended. The most effective method that can control this is the early detection of breast cancer. Early detection was seen as one of the most promising long-term strategies for preventing disease-related deaths ${ }^{10}$.

In Saudi, primary healthcare centers are the primary centers communicate with the patient and providing free public healthcare. However, unfortunately several women bypass early discovery and management possibilities related to the shortage of data, knowledge, and recognition of breast cancer, as well as cancer screening manners in general ${ }^{11}$.

Among local published health literacy studies. Few studies were found that examined the knowledge of female teachers in Saudi Arabia particular Buraydah. Therefore, our objectives are to assess the knowledge and screening behaviour of female teacher regarding breast cancer

\section{Methods, Study Design And Setting Study setting}

A cross-sectional study was conducted using a self-administered questionnaire among female teacher working at governmental secondary girls' school in Buraydah, Saudi Arabia, during the period from September 2018 to March 2019.

According to the database of the Menstrual of education in Buraydah, approximately 1739 female teacher work in $\mathbf{4 0}$ governmental secondary girls' school in the city of Buraydah. All female teacher working at governmental secondary girls' school primary in Buraydah were eligible for inclusion. All female teacher who were on an extended leave of duty, and teachers who declined to participate were excluded.

A cluster multistage random sampling technique was employed. For the purpose of the study, governmental secondary girls' school were clustered according to the city's geographic divisions into tow region (southern and northern), with 25-15 secondary girls' school in each region. Of these secondary girls' school, 10 schools' in each region were randomly chosen. Therefore, 20 secondary girls' school were included in the study.

\section{Sample size}

The sample size was calculated using a standard sample size equation " $n=z^{2} p(1-p) / e^{2 n}$ and an assumed proportion of $50 \%$ (proportion of high school females' teacher who had correct knowledge, and recognition of breast cancer, as well as cancer screening). Using a $95 \%$ confidence interval and a $5 \%$ margin of error, the sample size was estimated to be 316 and was adjusted to 378 to compensate for the non-response rate.

\section{Participants and survey instrument}

All females' teacher present at the time of data collection in the selected schools were included; hard copies of Loading [MathJax]/jax/output/CommonHTML/jax.js 
complete the anonymous self-administered survey in Arabic in order to assess their basic background knowledge.

The data were collected using a valid pretested structured self-administered questionnaire, adopted from a similar study carried out by Al-Zalabani et al. $2018^{12}$. The questionnaire is divided into three parts with a total of 39 questions. The first part includes socio-demographic data covered age, marital situation and family or friend's history of breast cancer. The second part assesses breast cancer knowledge and information associated to the practice based on 21 questions, including questions regarding the breast cancer risk factors (16 questions) and its clinical presentation (5 questions). The final question inquiries about the best time to perform BSE. The source of information about breast cancer was added. A score of " 1 " was assigned to correct answers while a score of "0" was assigned to wrong or don't know answers. The total score was computed for each participant and tested for normality using Shapiro-Wilk statistical test. The third part includes questions about participants practice concern such as BSE, clinical breast examination and mammogram. At the end of this part, barriers towards performing mammography were identified in 11 questions which marked as: 1 as totally disagree; 2 as disagree; 3 as neutral; 4 as agree; and 5 as totally agree. Their responses were re-coded as follows: totally agree and agree $=1$, whereas totally disagree, disagree, and neutral $=0$.

\section{Data management and analysis plan}

Data were coded and entered using SPSS 25.0 version statistical software. Descriptive statistics (mean, standard deviation, frequencies and percentages) were used to describe the quantitative and categorical variables. Pearson's Chi-square test was used to assess the association between the categorical variables. Non-parametric statistical tests (Mann-Whitney and Kruskal-Wallis) were applied to compare groups since the knowledge about breast cancer score was abnormally distributed as evidenced by significant Shapiro-Wilk test. A p-value of $\leq 0.05$ was used to

report the statistical significance and precision of the results.

\section{Ethical considerations}

Approval for the study was obtained from the Institutional research committee, College of Medicine, Qassim University (no. 20180615), AL Qassim, Saudi Arabia. Official approval letters were obtained from the minister of education in AL Qassim. Each participant received the questionnaire and was informed about the objective of the present study. The Institutional research committee has agreed that completing the questionnaire will imply consent.

\section{Results}

\section{Sample characteristics}

Three hundred and sixteen of female teachers completed the questionnaires (response rate of $100 \%$ ).

Table 1 shows participants' socio-demographic characteristics. More than half of the participants $(55.4 \%)$ 
breast cancer was reported among almost a quarter of them (25.9\%) while friend history of breast cancer was mentioned by $22.5 \%$ of the teachers.

Table 1

Socio-demographic characteristics

\begin{tabular}{|c|c|c|c|}
\hline \multicolumn{2}{|l|}{ Categorical variables } & \multirow{2}{*}{$\begin{array}{l}\mathbf{N} \\
175\end{array}$} & \multirow{2}{*}{$\begin{array}{l}\% \\
55.4 \%\end{array}$} \\
\hline Age & $<40$ & & \\
\hline & $\underset{40}{\geq}$ & 141 & $44.6 \%$ \\
\hline \multirow[t]{3}{*}{ Marital status } & single & 13 & $4.1 \%$ \\
\hline & Married & 290 & $91.8 \%$ \\
\hline & Divorced/Widowed & 13 & $4.1 \%$ \\
\hline \multirow[t]{2}{*}{ Family history of breast cancer } & Yes & 82 & $25.9 \%$ \\
\hline & No & 234 & $74.1 \%$ \\
\hline \multirow[t]{2}{*}{ Friend history of breast cancer } & Yes & 71 & $22.5 \%$ \\
\hline & No & 245 & $77.5 \%$ \\
\hline \multirow[t]{5}{*}{ Main source of information } & Reading & 40 & $12.65 \%$ \\
\hline & Tv & 24 & $7.59 \%$ \\
\hline & Educational lecture & 73 & $23.1 \%$ \\
\hline & Family/Friends & 44 & $13.92 \%$ \\
\hline & Internet & 135 & $42.72 \%$ \\
\hline
\end{tabular}

\section{Knowledge of Breast cancer}

The majority of teachers had adequate knowledge about breast cancer risk factor the most knowledgeable factors were oral contraceptive pills (76.9\%), smoking (72.5\%) and having the first baby after the age of 30 years (63.9\%). On the other hand, early menarche (<12 years) and late menopause (> 55 years) were recognized as risk factors by only $8.5 \%$ and $23.1 \%$ of the teachers, respectively. Moreover, majority of the teachers could recognize concerning symptoms and signs of breast cancer, breast mass (92.1\%), changes in colour of breast skin (75.6\%) and nipple discharge (72.5\%). The best time to perform BSE was correctly identified by $61.7 \%$ of the respondents (Table 2 ). The main source of information about breast cancer was the internet (42.7\%), followed by educational lectures $(23.1 \%)$. 
Table 2

participants knowledge statements to breast cancer $(\mathrm{N}=316)$

\begin{tabular}{|c|c|c|}
\hline & \multicolumn{2}{|c|}{ Correct Answer } \\
\hline & No. & $\%$ \\
\hline $\begin{array}{l}\text { Risk factors } \\
\text { Total duration of breast feeding ( }<1 \text { year) } \\
\text { Smoking } \\
\text { Obesity } \\
\text { Had first baby after } 30 \text { years } \\
\text { Have no children } \\
\text { Age between } 50 \text { and } 70 \text { years } \\
\text { Early menarche (<12 years) } \\
\text { Late menopause ( }>55 \text { years) } \\
\text { Antibiotics } \\
\text { Oral contraceptive pills } \\
\text { High dose of vitamins } \\
\text { Hormonal replacement therapy } \\
\text { Calcium therapy } \\
\text { Iron therapy } \\
\text { Vitamin D }\end{array}$ & $\begin{array}{l}155 \\
229 \\
132 \\
202 \\
78 \\
106 \\
27 \\
73 \\
110 \\
243 \\
99 \\
144 \\
140 \\
150 \\
133\end{array}$ & $\begin{array}{l}49.1 \% \\
72.5 \% \\
41.8 \% \\
63.9 \% \\
24.7 \% \\
33.5 \% \\
8.5 \% \\
23.1 \% \\
34.8 \% \\
76.9 \% \\
31.3 \% \\
45.6 \% \\
44.3 \% \\
47.5 \% \\
42.1 \%\end{array}$ \\
\hline $\begin{array}{l}\text { Symptoms and signs } \\
\text { Breast mass } \\
\text { Nipple discharge } \\
\text { Nipple ulcer } \\
\text { Changes in color of breast skin } \\
\text { Breast pain }\end{array}$ & $\begin{array}{l}291 \\
229 \\
208 \\
239 \\
184\end{array}$ & $\begin{array}{l}92.1 \% \\
72.5 \% \\
65.8 \% \\
75.6 \% \\
58.2 \%\end{array}$ \\
\hline The best time to perform BSE & 195 & $61.7 \%$ \\
\hline
\end{tabular}

The total knowledge score was abnormally distributed, as evidenced by significant Shapiro-Wilk test, $\mathrm{p}<$ 0.001 . The mean \pm SD score was $10.66 \pm 3.73$ (maximum possible score was 15 ) and the median (IQR) was 11 (8-13), (Fig. 1).

Table 3 demonstrate a statistically significant association between non-married teachers and low breast cancer knowledge in compare to others, $p=0.047$. Other studied factors (age, family and friend history of breast cancer) were not significantly associated with knowledge score. 
Table 3

Factors associated with breast cancer knowledge among governmental secondary girls' schools' female teachers, in Buraydah city, Saudi Arabia

\begin{tabular}{|c|c|c|c|c|}
\hline & \multicolumn{3}{|c|}{ Total Breast cancer knowledge score } & \multirow[t]{2}{*}{ p-value } \\
\hline & Median & IQR & Mean rank & \\
\hline $\begin{array}{l}\text { Age } \\
<40 \\
40-50\end{array}$ & $\begin{array}{l}11 \\
11\end{array}$ & $\begin{array}{l}8-13 \\
8-13\end{array}$ & $\begin{array}{l}158.47 \\
158.54\end{array}$ & $0.995^{\star}$ \\
\hline $\begin{array}{l}\text { Marital status } \\
\text { Single } \\
\text { Married } \\
\text { Divorced/widowed }\end{array}$ & $\begin{array}{l}8 \\
11 \\
10\end{array}$ & $\begin{array}{l}5-11.5 \\
8-13.25 \\
9.5-14\end{array}$ & $\begin{array}{l}97.42 \\
160.94 \\
165.15\end{array}$ & $0.047 *$ \\
\hline $\begin{array}{l}\text { Family history of breast cancer } \\
\text { Yes } \\
\text { No }\end{array}$ & $\begin{array}{l}11 \\
11\end{array}$ & $\begin{array}{l}8.75-13 \\
8-13.25\end{array}$ & $\begin{array}{l}166.39 \\
155.74\end{array}$ & 0.362 \\
\hline $\begin{array}{l}\text { Friend history of breast cancer } \\
\text { Yes } \\
\text { No }\end{array}$ & $\begin{array}{l}11 \\
11\end{array}$ & $\begin{array}{l}8-13 \\
8-13\end{array}$ & $\begin{array}{l}160.97 \\
157.78\end{array}$ & $0.795^{\star}$ \\
\hline
\end{tabular}

\section{Attitude practice}

The participants' practice towards breast screening examination are illustrated in Table 4. The majority $(57.3 \%)$ of the teachers are not performed BSE. Seventy-seven (42.5\%) of the teachers reported no actual cause prevent them from doing BSE. On the other hand, half (24.9\% and $24.9 \%)$ of them reported ignorance and afraid to discover a tumour are other reasons for not performing and 7.7\% don't believe on BSE. In contrast, $42.7 \%$ of teachers are performing BSE, and half of them (49.6\%) are performed it irregularly. 
Table 4

\begin{tabular}{|c|c|c|}
\hline & No. & $\%$ \\
\hline Frequency of BSE(n = 135) & 20 & $14.8 \%$ \\
\hline Monthly & 18 & $13.3 \%$ \\
\hline Every 3 months & 14 & $10.4 \%$ \\
\hline Every 6 months & 16 & $11.9 \%$ \\
\hline Every $>6$ months & 67 & $49.6 \%$ \\
\hline \multicolumn{3}{|l|}{ Irregular } \\
\hline Reasons for non-practicing BSE $(n=181)$ & 45 & $24.9 \%$ \\
\hline Ignorance & 45 & $24.9 \%$ \\
\hline Fear to discover tumor & 14 & $7.7 \%$ \\
\hline Don`t believe in its benefit & 77 & $42.5 \%$ \\
\hline \multicolumn{3}{|l|}{ Don`t know a reason } \\
\hline Date of last mammogram & 25 & $8.0 \%$ \\
\hline During this year & 13 & $4.1 \%$ \\
\hline Last year & 33 & $10.4 \%$ \\
\hline Before two years or more & 245 & $77.5 \%$ \\
\hline \multicolumn{3}{|l|}{ Never } \\
\hline You will perform mammogram in the future? & 41 & $13.0 \%$ \\
\hline Yes, within the coming month & 53 & $16.8 \%$ \\
\hline Yes, within the coming 6 months & 106 & $33.5 \%$ \\
\hline Yes, within the coming year & 6 & $1.9 \%$ \\
\hline Yes, within the coming 2 years & 19 & $6.0 \%$ \\
\hline No & 91 & $28.8 \%$ \\
\hline I don`t know & & \\
\hline
\end{tabular}

Table 5 illustrate no significant association between the following studied factor and the studied factors including (age, marital status, family and friend history of breast cancer, main source of information and level of breast cancer knowledge) with performing BSE or clinical breast examination. However, older teachers (4050) reported higher rates of performing mammogram compared to those aged $<40(29.1 \%$ versus 17.1$), p=$ 0.012. Also, teachers who had friends with breast cancer were practiced mammogram at higher rated than their counterparts $(25.3 \%$ versus $12.70, p=0.025$. 
Table 5

Association between socio-demographic data and performing BSE, clinical breast examination.

\begin{tabular}{|c|c|c|c|c|c|c|c|c|c|}
\hline & \multicolumn{3}{|l|}{ BSE } & \multicolumn{3}{|c|}{ Clinical BE } & \multicolumn{3}{|c|}{ Mammogram } \\
\hline & No & Yes & \multirow{3}{*}{$\begin{array}{l}\text { p- } \\
\text { value }\end{array}$} & No & Yes & \multirow{3}{*}{$\begin{array}{l}\mathrm{p}- \\
\text { value }\end{array}$} & No & Yes & \multirow{3}{*}{$\begin{array}{l}\text { p- } \\
\text { value }\end{array}$} \\
\hline & $\begin{array}{l}N= \\
181\end{array}$ & $\begin{array}{l}N= \\
135\end{array}$ & & $\begin{array}{l}N= \\
286\end{array}$ & $\begin{array}{l}\mathrm{N}= \\
30\end{array}$ & & \multirow{2}{*}{$\begin{array}{l}N=245 \\
N(\%)\end{array}$} & $\begin{array}{l}\mathrm{N}= \\
71\end{array}$ & \\
\hline & $\mathbf{N}(\%)$ & $\mathrm{N}(\%)$ & & $\mathrm{N}(\%)$ & $\mathrm{N}(\%)$ & & & $\mathbf{N}(\%)$ & \\
\hline \multirow{3}{*}{$\begin{array}{l}\text { Age } \\
<40(n=175) \\
40-50(n=141)\end{array}$} & $\begin{array}{l}95 \\
(54.3)\end{array}$ & $\begin{array}{l}80 \\
(45.7)\end{array}$ & \multirow[t]{3}{*}{0.231} & $\begin{array}{l}163 \\
(93.1)\end{array}$ & $\begin{array}{l}12 \\
(6.9)\end{array}$ & \multirow[t]{3}{*}{0.075} & $\begin{array}{l}145 \\
(82.9)\end{array}$ & $\begin{array}{l}30 \\
(17.1)\end{array}$ & \multirow[t]{3}{*}{0.012} \\
\hline & \multirow{2}{*}{$\begin{array}{l}86 \\
(61.0)\end{array}$} & \multirow{2}{*}{$\begin{array}{l}55 \\
(39.0)\end{array}$} & & & & & \multirow{2}{*}{$\begin{array}{l}100 \\
(70.9)\end{array}$} & \multirow{2}{*}{$\begin{array}{l}41 \\
(29.1)\end{array}$} & \\
\hline & & & & $(87.2)$ & (12.8) & & & & \\
\hline \multirow{2}{*}{$\begin{array}{l}\text { Marital status } \\
\text { Single }(n=13)\end{array}$} & \multirow{2}{*}{$\begin{array}{l}10 \\
(76.9)\end{array}$} & \multirow{2}{*}{$\begin{array}{l}3 \\
(23.1)\end{array}$} & \multirow[t]{4}{*}{0.256} & 12 & 1 & \multirow[t]{4}{*}{0.948} & \multirow{4}{*}{$\begin{array}{l}11(84.6) \\
224 \\
(77.2) \\
10(76.9)\end{array}$} & 2 & \multirow[t]{4}{*}{0.822} \\
\hline & & & & \multirow{2}{*}{$\begin{array}{l}262 \\
(90.3)\end{array}$} & & & & & \\
\hline Married $(n=290)$ & $\begin{array}{l}165 \\
(56.9)\end{array}$ & $\begin{array}{l}125 \\
(43.1)\end{array}$ & & & $\begin{array}{l}28 \\
(9.7)\end{array}$ & & & $\begin{array}{l}66 \\
(22.8)\end{array}$ & \\
\hline $\begin{array}{l}\text { Divorced/widowed } \\
(n=13)\end{array}$ & $\begin{array}{l}6 \\
(46.2)\end{array}$ & $\begin{array}{l}7 \\
(53.8)\end{array}$ & & $\begin{array}{l}12 \\
(92.3)\end{array}$ & $\begin{array}{l}1 \\
(7.7)\end{array}$ & & & $\begin{array}{l}3 \\
(23.1)\end{array}$ & \\
\hline $\begin{array}{l}\text { Family history of } \\
\text { breast cancer }\end{array}$ & $\begin{array}{l}40 \\
(48.8)\end{array}$ & $\begin{array}{l}42 \\
(51.2)\end{array}$ & \multirow[t]{3}{*}{0.071} & $\begin{array}{l}73 \\
(89.0)\end{array}$ & $\begin{array}{l}9 \\
(11.0)\end{array}$ & \multirow[t]{3}{*}{0.590} & \multirow{3}{*}{$\begin{array}{l}59(72.0) \\
186 \\
(79.5)\end{array}$} & $\begin{array}{l}23 \\
(28.0)\end{array}$ & \multirow[t]{3}{*}{0.159} \\
\hline Yes $(n=82)$ & \multirow{2}{*}{$\begin{array}{l}141 \\
(60.3)\end{array}$} & 93 & & 213 & 21 & & & 48 & \\
\hline No $(n=234)$ & & & & & ( & & & & \\
\hline Friend history of & $\begin{array}{l}41 \\
(577)\end{array}$ & $\begin{array}{l}30 \\
(423)\end{array}$ & 0.928 & $\begin{array}{l}66 \\
(930)\end{array}$ & 5 & 0.424 & $62(87.3)$ & 9 & 0.025 \\
\hline & & & & & & & $183(74.7)$ & & \\
\hline Yes $(n=71)$ & $\begin{array}{l}140 \\
(57.1)\end{array}$ & $\begin{array}{l}105 \\
(42.9)\end{array}$ & & $\begin{array}{l}220 \\
(89.8)\end{array}$ & $\begin{array}{l}25 \\
(10.2)\end{array}$ & & & $\begin{array}{l}62 \\
(253)\end{array}$ & \\
\hline No $(n=245)$ & & & & & & & & & \\
\hline
\end{tabular}

The Participant's barriers toward breast screening are illustrated in Table 5. Most of them strongly agreed with the following statements: fear to discover something abnormal; being busy, don`t know how to arrange to perform it; exposed to more unneeded radiation $(22.1 \%, 20.5 \%, 13.6 \%, 13.6 \%$; respectively). Table 6 
Table 6

Participant's barriers toward breast screening ( $N=316)$

\begin{tabular}{|lll|}
\hline Strong agreement toward the following statement & No. & $\%$ \\
\hline Fear to discover something abnormal & 70 & $22.1 \%$ \\
\hline I don't know how it will be performed & 41 & $12.9 \%$ \\
\hline I don't know how to arrange to perform it & 43 & $13.6 \%$ \\
\hline It is shameful for women & 30 & $9.4 \%$ \\
\hline It needs a long time & 28 & $8.8 \%$ \\
\hline It is a painful procedure & 29 & $9.1 \%$ \\
\hline Poor communication with mammography personnel & 19 & $6 \%$ \\
\hline Women are exposed to more unneeded radiation & 43 & $13.6 \%$ \\
\hline I am busy & 65 & $20.5 \%$ \\
\hline Some issues in my life are more important & 41 & $12.9 \%$ \\
\hline I am old and don't need such scan & 11 & $3.4 \%$ \\
\hline
\end{tabular}

\section{Discussion}

The purpose of this study was to assess the knowledge, and screening behaviour of female teacher regarding breast cancer.

The majority of participants in this study have a moderate knowledge of breast cancer risk factors and clinical presentation as the median score (IQR) was 11 (8-13) out of a maximum possible of 15 . The good knowledge was observed regarding some risk factors such as oral contraceptive pills, smoking and having the first baby after the age of 30 years. In a study carried out previously in Riyadh ${ }^{14}$, quite similar results were reported. In contrast; another similar study was performed in Buraydah ${ }^{8}$ that compared the Knowledge, Attitudes, and Practices of Breast Cancer and Screening in Female Teachers. They concluded the majority $(90 \%)$ of the participants have a low knowledge score. This represent significant improving the level of knowledge of female teachers. Therefore, our findings could promote the implementation of training programs on breast knowledge. Internationally, an intermediate level of knowledge about risk factors related to breast cancer was observed among majority of female university students In Uganda ${ }^{15}$.

It has been documented that BSE practice makes women more aware of their breasts, which consequently may result in earlier diagnosis of breast cancer ${ }^{16}$. In the present study, $42.7 \%$ of the teachers reported performing BSE; among them, it was performed on monthly basis by only $14.8 \%$. In a recent study carried out in Al-Madinah ${ }^{12}$ among attendees of primary healthcare centers, the rate of performing BSE was $38.5 \%$. Different rates were reported elsewhere. In Hong Kong $(52 \%)^{17}$, in KSA nursing students $(66 \%)^{18}$, in Jordon $(37.5 \%)^{19}$ and in Uganda $(76.5 \%)^{15}$. The difference in rates between various studies could be attributed to Loading [MathJax]/jax/output/CommonHTML/jax.js , the cultural and religious background of the community. 
The rate of previous performing of mammogram in the present study was $22.5 \%$, despite mammogram facility is usually provided free to Saudi women. This figure is slightly lower than that has been reported by AlAl-Zalabani $\mathrm{AH}$ et al $(27.7 \%)^{12}$. Restricting analysis to teachers ages over 40 years showed rates of $39 \%$ and $29.1 \%$ for BSE and mammogram, respectively. In a study carried out Riyadh region among women attended primary health centers, BSE and mammogram performance were reported by $23.1 \%$ and $14.8 \%$ of them, respectively 20 . The same low rate of mammogram performance has been observed in another Saudi study carried out in Dammam ${ }^{21}$. Al-Wassia et al (2017) reported that around 40\% of the Saudi women ever having a mammogram 22 . Ahmed et al (2015) reported that $13 \%$ of the Saudi females have performed mammography ${ }^{23}$. El Bcheraoui and colleagues (2015) reported that $92 \%$ of Saudi women aged 50 years or older never having a mammogram ${ }^{24}$. Therefore, routine mammography screening is not always possible in developing countries, including Saudi Arabia. Thus, an emphasis should be directed to encourage Saudi women to practice periodic clinical breast examination and BSE. Although a debate still exists concerning the effectiveness of BSE in reducing mortality from breast cancer ${ }^{25}$, it remains an important tool for early detection of breast cancer in many parts of the world ${ }^{26}$.

In the current study, the commonest reported barriers of breast cancer screening were fear to discover something abnormal (50.9\%), being busy (49.4\%), they don't know how to arrange to perform it (40.8\%) and they don't know how it will be performed (37.3\%). In a study carried out in Al-Madinah among primary healthcare centers attendees, ${ }^{12}$ incorrect beliefs about mammography as being a painful procedure and the exposure of women to more unneeded radiation were the main barriers, However, also, bad communication with mammography personnel and the perception of mammography as being shameful were also important barriers in that study. The difference between results of the two studies is expected due to difference in the characteristics of the target population.

\section{Conclusions}

This study indicates that breast cancer knowledge among governmental female secondary school teachers in Buraydah city, Saudi Arabia is overall insufficient, regarding risk factors and clinical presentation.

Performance of breast cancer screening techniques is not enough. Therefore, according to this conclusion, improving knowledge regarding breast cancer risk factors, presentation and screening tools as BSE and mammogram through educational programs is highly recommended for prevention and early detection. Primary health care professionals should have a role in conveying correct information regarding breast cancer and its early detection during regular physician office visits for other health problems. Encouraging practice of BSE through the audio-visual media, lectures and symposia is needed.

\section{Declarations}

\section{Conflict of interest}

The authors have declared no competing interests.

\section{Authors' contributions}


Sharifa Khalid Alduraibi was responsible for the conception of the research idea and the study design, data collection, analysis, interpretation, and drafting of the manuscript.

\section{Sources of Funding}

There was no funding for this study.

\section{Acknowledgements}

We would like to thank all female teacher working at governmental secondary girls' school in Buraydah, Saudi Arabia in $b$ for their volunteering to participate in the study.

\section{References}

1. Ferlay J, Shin HR, Bray F, Forman D, Mathers C, Parkin DM. GLOBOCAN 2008 v1. 2, Cancer Incidence and Mortality Worldwide: IARC CancerBase No. 10. Lyon: International Agency for Research on Cancer; 2011. globocan. iarc. f r (accessed March 28, 2013). 2012.

2. Pizot C, Boniol M, Boyle P, Autier P. Abstract P5-08-04: Overview of breast cancer mortality trends in the world.

3. Osterman MJ, Kochanek KD, MacDorman MF, Strobino DM, Guyer B. Annual summary of vital statistics: 2012-2013. Pediatrics. 2015 Jun 1;135(6):1115-25.

4. Ibrahim EM, Al-Gahmi AM, Zekri JM, Awadalla SS, Elkhodary TR, Fawzy EE, Bahadur YA, Elsayed ME, Zeeneldin A, Al-Ahmadi RH, Linjawi AH. Pre-operative systemic therapy in locally advanced breast cancer: a single institution experience. ecancermedicalscience. 2009;3.

5. Jemal A, Siegel R, Ward E, Hao Y, Xu J, Thun MJ. Cancer statistics. Ca Cancer J Clin. 2009 Apr 22;59(4).

6. Alghamdi IG, Hussain II, Alghamdi MS, El-Sheemy MA. The incidence rate of female breast cancer in Saudi Arabia: an observational descriptive epidemiological analysis of data from Saudi Cancer Registry 2001-2008. Breast Cancer: Targets Therapy. 2013;5:103.

7. Lafortune G, De Looper M, Balestat G. Health at a glance 2009: OECD indicators. Paris: OECD Publishing; 2009.

8. Dandash KF, Al-Mohaimeed A. Knowledge, attitudes, and practices surrounding breast cancer and screening in female teachers of Buraidah, Saudi Arabia. International journal of health sciences. 2007 Jan;1(1):61.

9. Lee CH, Dershaw DD, Kopans D, Evans P, Monsees B, Monticciolo D, Brenner RJ, Bassett L, Berg W, Feig S, Hendrick E. Breast cancer screening with imaging: recommendations from the Society of Breast Imaging and the ACR on the use of mammography, breast MRI, breast ultrasound, and other technologies for the detection of clinically occult breast cancer. Journal of the American college of radiology. 2010 Jan $1 ; 7(1): 18-27$.

10. Porter PL. Global trends in breast cancer incidence and mortality. Salud publica de Mexico. 2009;51:s1416. 
11. El Bcheraoui C, Basulaiman M, Wilson S, Daoud F, Tuffaha M, AlMazroa MA, Memish ZA, Al Saeedi M, Mokdad AH. Breast cancer screening in Saudi Arabia: free but almost no takers. Plos one. 2015;10(3).

12. Al-Zalabani AH, Alharbi KD, Fallatah NI, Alqabshawi RI, Al-Zalabani AA, Alghamdi SM. Breast cancer knowledge and screening practice and barriers among women in Madinah, Saudi Arabia. Journal of Cancer Education. 2018 Feb 1;33(1):201-7.

13. Saggu S, Rehman H, Abbas ZK, Ansari AA. Recent incidence and descriptive epidemiological survey of breast cancer in Saudi Arabia. Saudi medical journal. 2015 Oct;36(10):1176.

14. Alam AA. Knowledge of breast cancer and its risk and protective factors among women in Riyadh. Annals of Saudi medicine. 2006 Jul;26(4):272-7.

15. Godfrey K, Agatha T, Nankumbi J. Breast cancer knowledge and breast self-examination practices among female university students in Kampala, Uganda: a descriptive study. Oman Medical Journal. 2016 Mar;31(2):129.

16. World Health Organization. National cancer control programmes: policies and managerial guidelines. World Health Organization; 2002.

17. Ng KK, Fung SY, Chow LW. Practice of breast self-examination among high risk Chinese women in Hong Kong. Chinese medical journal. 2000 Dec;113(12):1100-3.

18. Alsaif AA. Breast self-examination among Saudi female nursing students in Saudi Arabia. Saudi Med J. 2004 Nov;1(11):1574-8. 25(.

19. Alsaraireh A, Darawad MW. Breast cancer awareness, attitude and practices among female university students: A descriptive study from Jordan. Health care for women international. 2018 May 4;39(5):57183.

20. Ravichandran K, Al-Hamdan NA, Mohamed G. Knowledge, attitude, and behavior among Saudis toward cancer preventive practice. Journal of Family Community Medicine. 2011 Sep;18(3):135.

21. Latif R. Knowledge and attitude of Saudi female students towards breast cancer: A cross-sectional study. Journal of Taibah University Medical Sciences. 2014 Dec 1;9(4):328 - 34.

22. Al-Wassia RK, Farsi NJ, Merdad LA, Hagi SK. Patterns, knowledge, and barriers of mammography use among women in Saudi Arabia. Saudi medical journal. 2017 Aug;38(9):913.

23. Abdallah AS, El-Gharabawy RM, Al-suhaibany HO. Knowledge, attitude and practice about breast cancer among women in Saudi Arabia. International Archives of Medicine. 2015 Oct 28;8.

24. El Bcheraoui C, Basulaiman M, Wilson S, Daoud F, Tuffaha M, AlMazroa MA, Memish ZA, Al Saeedi M, Mokdad AH. Breast cancer screening in Saudi Arabia: free but almost no takers. Plos one. 2015;10(3).

25. Thomas DB, Gao DL, Ray RM, Wang WW, Allison CJ, Chen FL, Porter P, Hu YW, Zhao GL, Pan LD, Li W. Randomized trial of breast self-examination in Shanghai: final results. Journal of the national Cancer Institute. 2002 Oct 2;94(19):1445-57.

26. Anderson BO, Yip CH, Smith RA, Shyyan R, Sener SF, Eniu A, Carlson RW, Azavedo E, Harford J. Guideline implementation for breast healthcare in low-income and middle-income countries: Overview of the Breast Health Global Initiative Global Summit 2007. Cancer. 2008 Oct 15;113(S8):2221-43. 


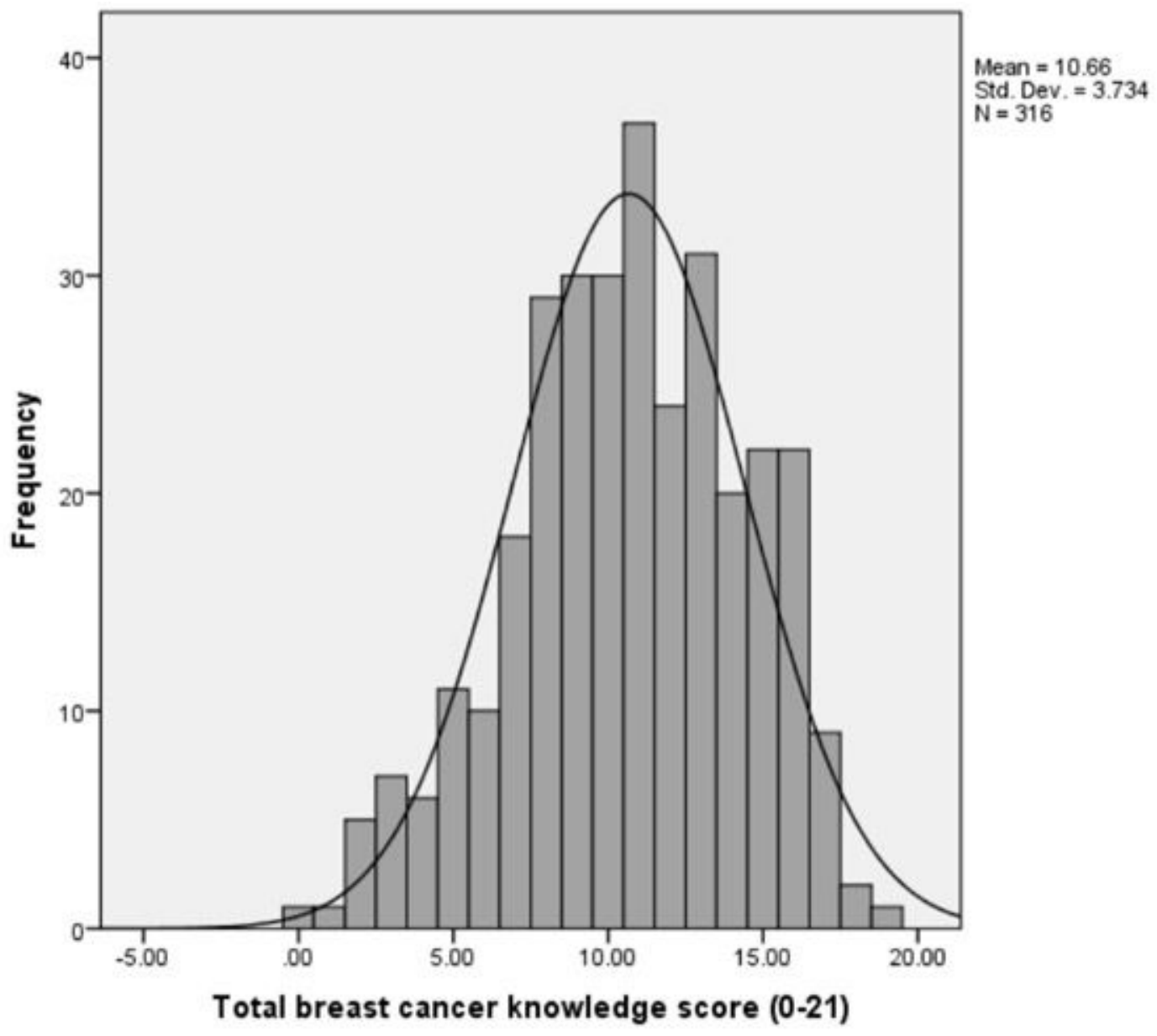

Figure 1

Distribution of the total breast cancer knowledge score among governmental secondary girls' schools' female teachers, in Buraydah city, Saudi Arabia 